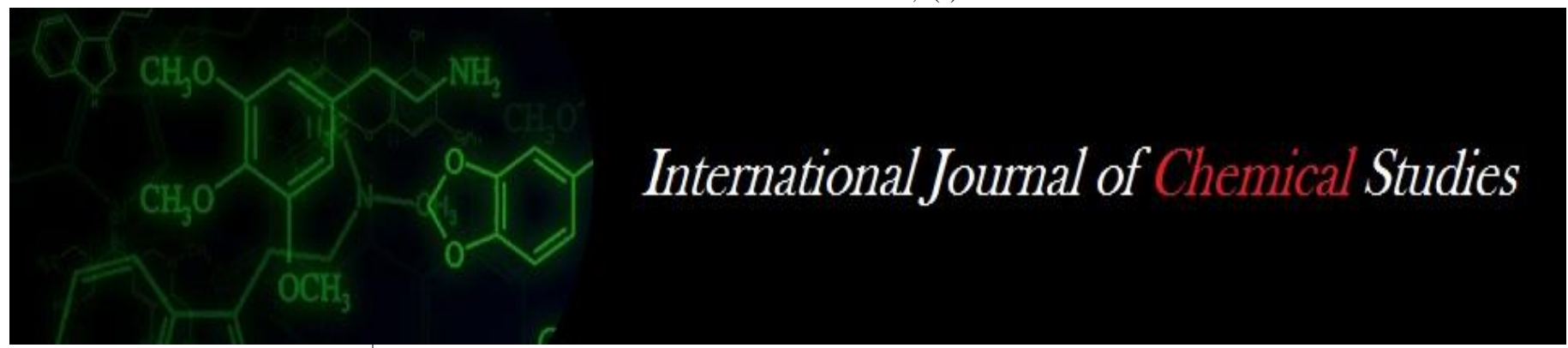

P-ISSN: 2349-8528

E-ISSN: 2321-4902

www.chemijournal.com

IJCS 2021; 9(1): 1393-1395

(C) 2021 IJCS

Received: 13-11-2020

Accepted: 21-12-2020

Roshmi Rekha Saikia Subject Matter Specialist

Department of Community Science, KVK, Bongaigaon,

AAU, Assam, India

Chinmoy Kumar Sarma

Head, KVK, Bongaigaon, AAU,

Assam, India

Bhaskarjyoti Sarma

Assistant Professor, Department of Horticulture, SCS College of

Agriculture, AAU, Assam, India

Corresponding Author: Roshmi Rekha Saikia

Subject Matter Specialist

Department of Community

Science, KVK, Bongaigaon,

AAU, Assam, India

\section{Influence of air hanging stalks techniques in increasing shelf life of tomatoes}

\author{
Roshmi Rekha Saikia, Chinmoy Kumar Sarma and Bhaskarjyoti Sarma
}

DOI: https://doi.org/10.22271/chemi.2021.v9.i1t.11420

\begin{abstract}
Tomato (Lycopersicon esculentum L.) is one of the most widely consumed fresh vegetables. But, it rapidly deteriorate soon after harvesting like other perishable fruits and vegetables. So, this study was conducted for development of a cheap storage technique of tomato for the benefit of the farmers. In the study tomatoes were harvested at different stages of maturity, viz., immature green, mature green, turning (breaker stage), pink, hard ripe and over ripe. It was observed that the air hanging stalk technique of tomato storage was far superior than farmers' practice in all aspects. Again, among different stages of harvest, pink stage can be considered as the best in terms of storability and acceptability.
\end{abstract}

Keywords: Influence, hanging, techniques, increasing, tomatoes

\section{Introduction}

Tomato (Lycopersicon esculentum L.) is one of the most widely consumed fresh vegetables. It is one of the most popular and widely grown vegetable crops in the world. It belongs to the family Solanaceae. According to Mohan et al. (2016) ${ }^{[1]}$, tomato with a total production of around 160 million tons per year, is the second most important source of nourishment (after potatoes) for the World's population. However, its highly perishable nature limits its postharvest life. Being a climacteric and perishable vegetable tomatoes to have a very short life span, usually 2-3 weeks. Thus, an increase in the storage life and improvement of tomato fruit quality is really desirable. Temperature and relative humidity management to extend shelf life and maintain postharvest quality of perishables is the main problem. Fresh market tomatoes are a popular and versatile fruit vegetable, making significant contributions to human nutrition throughout the world for their content of sugars, acids, vitamins, minerals, lycopene and other carotenoids, among other constituents (Toor and Savage, 2006) ${ }^{[2]}$. Tomato like most fruits and vegetables are classified as perishables, because of its tendency to rapidly deteriorate soon after harvesting (Frazier and Westholf, 1986) ${ }^{[3]}$. Though mechanical refrigerators are the best option to extend shelf life and maintain postharvest quality, it is unaffordable for all the farmers. So development of cheap storage is important task to overcome the problem.

Though proper harvesting time determines the nutritional contents as well as storage durability of the fruit, suitable harvesting stage (maturity) of the fruit and optimum ripening conditions to have the best quality and longer storage of tomato has not completely been recognized for developing countries. Improper harvesting stage, ripening conditions and lack of suitable storage facilities cause a glut during the peak harvesting period and a large portion of yield is sold very cheap. After harvest, ripening continues and tomatoes can became overripe very rapidly. Depending on the humidity and temperature it ripens very soon, ultimately resulted in poor quality as the fruit become soft and unacceptable (Ullah, 2009) ${ }^{[4]}$. Hence, it must be harvested at the right time because overripe tomato is more susceptible to physical injury than ripe and pink ones (Ullah, 2009) ${ }^{[4]}$.

Keeping in mind all the aspects in regards to tomato ripening, this study was undertaken to develop a low cost storage technology for the farmers.

\section{Materials and Methods}

Study area: The study was conducted at farmer's field at Chitkagaon and Manikpur village of Bongaigaon district of Assam. Chitkagaon is located at a latitude $90.5991^{\circ} \mathrm{E}$ and longitude of 
$26.4772^{\circ} \mathrm{N}$ and Manikpur is located at a latitude $90.8029{ }^{\circ} \mathrm{E}$ and longitude of $26.4641^{\circ} \mathrm{N}$. In Bongaigaon the climate is warm and the summers are much rainier than the winters in Bongaigaon. The average annual temperature in Bongaigaonis $24.3^{\circ} \mathrm{C}$ and precipitation is $3159 \mathrm{~mm}$ per year.

\section{Experimental materials}

Sample tomatoes were collected from farmers at various maturity stages. Followings are the various stages that took for the whole experimental period:

Table 1: Show the Characteristics

\begin{tabular}{|c|c|}
\hline Stage & Characteristics \\
\hline Immature green & Seeds and jelly-like substance surrounding the seeds not yet formed \\
\hline Mature green & Fully grown fruit shows a brownish ring on the stem scar, and blossom end turns yellowish green; seeds are \\
& surrounded by a jelly-like substance \\
\hline Turning (breaker stage) & One-quarter of the surface at blossom end appears pink \\
\hline Pink & Three-quarters of the surface appears pink \\
\hline Hard ripe & Nearly all red or pink, but flesh is firm \\
\hline Over-ripe & Fully red and soft \\
\hline
\end{tabular}

Treatments: For all the maturity stages of tomato, following two treatments were followed:

T1: Tomatoes tied with stalks is hanged with thread (Diameter 1-2 mm) Rope are tied with two sides of a bamboo Pool (6 ft height from ground level, $2 \mathrm{ft}$ below roof for free air circulation). To protect direct light from the roof they kept ceiling of thick cotton cloth at a distance of $1.5 \mathrm{ft}$ from the roof

T2: Farmer's Practice (without treatment)

Observations: Physiological weight loss, Rotting Percentage, Organoleptic Parameters (1-9 hedonic Scale) like colour, taste etc., Shelf life (days) were collected during the experimental period from the total population for every 3 days of interval (0, 3, 6 and 9 days). Physical and subjective data was taken from the population of tomato fruits during the storage period as follows.

Shelf life: Shelf life (days) were collected and average temperature and humidity for each week was recorded.
Physiological weight loss: Physiological weight loss was calculated using the following formula:

$$
\text { PLW }(\%)=\frac{\text { Initial wight }(\mathrm{g})-\text { Final weight }(\mathrm{g})}{\text { Initial weight }(\mathrm{g})}
$$

Rotting Percentage: Any decay loss during storage was assessed. The percentage of decayed fruits was determined by dividing number of decayed fruits to number of total tomatoes hanged.

Organoleptic Parameters: Parameters like colour, taste etc. were assessed by 1-9 hedonic scale.

\section{Result and Discussion}

Shelf life: The shelf life was significantly influenced by temperature and humidity during the storage period. During storage period in air hanging stalks tomatoes were found fresh for 21 days at an average temperature of min $17.39{ }^{\circ} \mathrm{C}$ and $\max 29^{\circ} \mathrm{C}$ and with an average $72 \%$ humidity (Table 2 ).

Table 2: Average temperature and humidity during study period

\begin{tabular}{|c|c|c|c|c|}
\hline Month & Week & Minimum Temperature $\left({ }^{\circ} \mathbf{C}\right)$ & Maximum Temperature $\left({ }^{\circ} \mathrm{C}\right)$ & Average Humidity percentage \\
\hline \multirow{4}{*}{ March } & $1^{\mathrm{st}}$ & 14.7 & 27.2 & \multirow{4}{*}{68} \\
\hline & $2^{\text {nd }}$ & 15.8 & 29.0 & \\
\hline & $3^{\text {rd }}$ & 16.7 & 29.1 & \\
\hline & $4^{\text {th }}$ & 17.4 & 30.0 & \\
\hline \multirow{4}{*}{ April } & $1^{\mathrm{st}}$ & 18.7 & 30.0 & \multirow{4}{*}{76} \\
\hline & $2^{\text {nd }}$ & 18.4 & 30.1 & \\
\hline & $3^{\text {rd }}$ & 18.7 & 29.1 & \\
\hline & $4^{\text {th }}$ & 18.7 & 27.5 & \\
\hline
\end{tabular}

Generally farmers are used to store tomatoes in a corner of a verandah or any shaded places after harvesting. During the storage period of this farmers' practice tomatoes were found fresh for 09 days at an average temperature of min $17.39{ }^{\circ} \mathrm{C}$ and max $29^{\circ} \mathrm{C}$ and with an average $72 \%$ humidity. So, the air hanging stalk method of storage proved to be superior in comparision to farmers' practice.

Physiological weight loss: In case of pink harvested tomatoes the highest percentage of weight loss of $8.01 \%$ was noticed on $21^{\text {st }}$ day of study period, but in case of green harvested tomatoes the highest percentage of weight loss was found only $5.20 \%$ on the same day (Table 3 ). In both the cases the highest weight loss percentage was seen at the end of storage period. This is due to the ripening process in tomatoes is climacteric which showed a sudden increase in ethylene production and respiration rate. This higher respiration rate also resulted in higher transpiration of water from the fruit surface which led to increase in percentage of weight loss (Sabir et al., 2004) ${ }^{[5]}$. Thus, physiological weight loss in tomato fruits was influenced by lengthening of storage period. Again, high temperature during that period also influences the physiological weight loss of tomato. Prolux et al. (2005) ${ }^{[6]}$, in their study, noticed that high storage temperature leads to accelerated water loss and subsequently to shriveling and softening of the fruit.

Table 3: Physiological loss of weight (\%) in air hanging stalk technique

\begin{tabular}{|c|c|c|c|c|c|c|c|}
\hline \multirow{2}{*}{ Stage of harvesting } & \multicolumn{7}{|c|}{ Storage Period (Days) } \\
\cline { 2 - 8 } & $\mathbf{3}$ & $\mathbf{6}$ & $\mathbf{9}$ & $\mathbf{1 2}$ & $\mathbf{1 5}$ & $\mathbf{1 8}$ & $\mathbf{2 1}$ \\
\hline Pink harvested Tomatoes & 7.06 & 7.23 & 7.35 & 7.70 & 7.75 & 7.82 & 8.01 \\
\hline Green harvested Tomatoes & 4.32 & 4.86 & 5.01 & 5.12 & 5.15 & 5.18 & 5.20 \\
\hline
\end{tabular}


From Table 4, it is evident that the physiological loss of weight $(\%)$ in in farmers' practice was much higher. So, the air hanging stalk technique proved to be better in checking the loss of moisture from the fruits during storage.

Table 4: Physiological loss of weight (\%) in farmers' practice

\begin{tabular}{|c|c|c|c|}
\hline \multirow{2}{*}{ Stage of harvesting } & \multicolumn{3}{|c|}{ Storage Period (Days) } \\
\cline { 2 - 4 } & $\mathbf{3}$ & $\mathbf{6}$ & $\mathbf{9}$ \\
\hline Pink harvested Tomatoes & 12.45 & 12.78 & 13.05 \\
\hline Green harvested Tomatoes & 08.22 & 08.56 & 09.23 \\
\hline
\end{tabular}

Rotting percentage: Until 21 days of storage, none of the tomato fruits became rotten which could be due to the low relative humidity of the storage through hanging stalks $(72 \%)$ which limits the multiplication of microorganism. Heavy rotting was noticed in the fruits stored in farmers' practice, even in $9^{\text {th }}$ day itself (Table 5).

Table 5: Rotting (\%) in farmers' practice

\begin{tabular}{|c|c|c|c|}
\hline \multirow{2}{*}{ Stage of harvesting } & \multicolumn{3}{|c|}{ Storage Period (Days) } \\
\cline { 2 - 4 } & $\mathbf{3}$ & $\mathbf{6}$ & $\mathbf{9}$ \\
\hline Pink harvested Tomatoes & 67.31 & 76.12 & 82.15 \\
\hline Green harvested Tomatoes & 56.37 & 70.45. & 74.56 \\
\hline
\end{tabular}

Organoleptic parameters: It is evident from Table 6 that, color of tomato fruits was remained getting better with advances in ripening in air hanging stalk technique of storage. It is clearly shown that as the ripening preceded the color of fruits changed from mature green to red on the base of tomato fruit classifying ripening stages as green, mature green, pink red and red. From mature green to turning stage, the color of fruits changed with poor to fair. At this stage the chlorophyll pigment start to disappear and beta carotene production was initialized and at maximum. When stage advances from pink to pink-red, the color of all fruits was in the range of good to very. At this stage lycopene production has started producing red color and masking the yellow color of beta carotene (Salunkhe and Desai, 1984) ${ }^{[7]}$.

Table 6: Organoleptic parameters in air hanging stalk technique

\begin{tabular}{|c|c|c|c|c|}
\hline & Mature green & Advanced green & Pink & red \\
\hline Colour & Like slightly & Like moderately & $\begin{array}{c}\text { Like very } \\
\text { much }\end{array}$ & $\begin{array}{c}\text { Like } \\
\text { extremely }\end{array}$ \\
\hline Taste & $\begin{array}{c}\text { Neither like } \\
\text { nor dislike }\end{array}$ & Like slightly & $\begin{array}{c}\text { Like very } \\
\text { much }\end{array}$ & $\begin{array}{c}\text { Like } \\
\text { extremely }\end{array}$ \\
\hline
\end{tabular}

The present study revealed that storage of tomato by farmers' practice showed lower overall acceptability as compared to storage of tomato through air hanging stalks (Table 7). At the red stage of ripening, farmer's practice showed a below overall acceptability scores which was due to its rapid turning of unacceptable color and loss of its content due to high temperature of the surrounding environment. On basis of overall acceptability, the tomatoes stored through air hanging stalks showed the excellent overall acceptability. The main reason behind this improvement was due to the prevention of tomato from decay organism and the fruit will have stored reserve which is protected from adverse condition.

Table 7: Organoleptic parameters in farmers' practice

\begin{tabular}{|c|c|c|c|c|}
\hline & Mature green & Advanced green & Pink & red \\
\hline Colour & $\begin{array}{c}\text { Neither like nor } \\
\text { dislike }\end{array}$ & Like slightly & $\begin{array}{c}\text { Like } \\
\text { moderately }\end{array}$ & $\begin{array}{c}\text { Like very } \\
\text { much }\end{array}$ \\
\hline Taste & $\begin{array}{c}\text { Neither like nor } \\
\text { dislike }\end{array}$ & Like slightly & $\begin{array}{c}\text { Like } \\
\text { moderately }\end{array}$ & $\begin{array}{c}\text { Like very } \\
\text { much }\end{array}$ \\
\hline
\end{tabular}

\section{Conclusion}

From the present study, it may be concluded that the air hanging stalk technique of tomato storage is an excellent way of storing the harvested tomato fruits. In all aspects, the technique proved its superiority over traditional farmers' practice. Again, among different stages of harvest, pink stage can be considered as the best in terms of storability and acceptability.

\section{Acknowledgement}

The financial support from ICAR, New Delhi through KVK system of Assam Agricultural University, Assam is gratefully acknowledged.

\section{Reference}

1. Mohan V, Gupta S, Thomas S, Mickey H, Charakana C, Chauhan VS et al. Tomato Fruits Show Wide Phenomic Diversity but Fruit Developmental Genes Show Low Genomic Diversity. PLoS ONE 2016;11(4):1-23.

2. Toor RK, Savage GP. Effect of semi-drying on the antioxidant components of tomatoes. Food Chem 2006;94(1):90-97.

3. Frazier WC, Westholf DC. Food Microbiology. McgrawHill Book Copuy, New York 1986.

4. Ullah J. Storage of fresh tomatoes to determine the level of $\left(\mathrm{CaCl}_{2}\right)$ coating and optimum temperature for extended shelf life, Asian Institute of Technology, Bangkok, Thailand 2009.

5. Sabir MS, Shah SZA, Afzal A. Effect of chemical treatment, wax coating, oil dipping and different wrapping materials on physio- chemical characteristics and storage behaviour of apple (Malus domestica Borkh). Pak. J Nutr 2004;3(2):122-127.

6. Prolux E, Nunes MCN, Emond JP, Brecht JK. Quality attributes limiting papaya postharvest life at chilling and non-chilling temperatures. Proc. Flor. State Hort. Soc 2005;118:389-395.

7. Salunkhe DK, Desai BB. Post-harvest biotechnology of vegetables. Vol 1, CRC Press, Inc. Boca Raton, Florida, US 1984. 